\title{
Edaphic relations of Cirsium cassium Davis \& Parris (Asteraceae), a local
endemic from Hatay (Turkey)
}

Volkan ALTAY ${ }^{1 *}$, Mehmet Yahya DALOĞLU ${ }^{1}$, Munir OZTURK ${ }^{2}$

${ }^{I}$ Biology Department, Faculty of Science \& Arts, Mustafa Kemal University, Antakya-Turkey

${ }^{2}$ Centre for Environmetal Studies and Botany Department, Ege University, Izmir, Turkey

*volkanaltay34@gmail.com

\section{Hatay (Türkiye)'dan yerel bir endemik olan Cirsium cassium Davis \& Parris (Asteraceae)'un edafik ilişkileri}

\begin{abstract}
This study was carried out during 2012-2015. Our aim was to determine the soil-plant relationships of Cirsium cassium distributed in Hatay province of Turkey. This local endemic species was collected from three different localities in Hatay. The analysis of soil samples revealed that this endemic plant prefers clayey-loam, nonsaline, slightly alkaline soils with a high lime content. The nitrogen and potassium contents are of sufficient level but the soils are rich in phosphorus. Analysis of root, stem and leaf shows that nitrogen and phosphorus are below normal values in all plant organs; sodium is above the normal value in all plant parts. The potassium is below normal values in root and stem, but above normal values in leaf.
\end{abstract}

Key words: Soil-Plant interactions, endemic plant, conservation

Özet: Bu çalışma 2012-2015 yılları arasında gerçekleştirildi. Amaç, Hatay ilinde dağılmış olan Cirsium cassium'un toprak-bitki ilişkilerini belirlemeyi amaçladık. Bu lokal endemik tür, araştırma alanında üç farklı lokaliteden toplanmıştır. Toprak örneklerine ait analizlere göre, bu endemik bitki, yüksek kireç içeriğine sahip killi-tınlı, tuzsuz, hafif alkalin toprakları tercih ettiğini ortaya koydu. Azot ve potasyum içeriği yeterli seviyededir, ancak topraklar fosfor bakımından zengindir. Kök, gövde ve yaprak analizleri, tüm bitki organlarında azot ve fosforun normal değerlerin altında olduğunu; sodyum, tüm bitki kısımlarında normal değerin üzerindedir. Potasyum, kök ve gövde normal değerlerin altında ancak yapraklarda normal değerlerin üzerindedir.

Anahtar kelimeler: Bitki-toprak ilişkileri, endemik bitki, koruma

\section{Introduction}

Phytogeographically Turkiye occupies an important position in the world from the viewpoint of plant genetic resources and genetic diversity (Ozturk et al., 2016). The report published by WWF for Turkiye includes 122 important plant areas but, the nature association has identified 305 key biodiversity areas on the basis of endemism in the country (Eken et al., 2016; Ozturk et al., 2016). The fundamentals of species conservation are determination of distribution and ecology of the species (Çınar and Tuğ, 2015). The effective factors of the distribution areas are the macro and micro climatic features, habitats and soil characteristics of the plant niches together with the interactions with other species (Çınar and Tuğ, 2015; Ozturk et al., 2016).

Many endemic taxa show a restricted distribution, which is one of the main subjects of several ecological and phylogenetical studies (Çınar and Tuğ, 2015; Ozturk et al., 2016). The main reasons for this are listed as low ecological tolerance, specialized habitat requirements, low dispersal ability, and/or low reproductive capacity. Many plant endemics in Turkiye have only one distribution area, their systematics is well-known but information on their ecology, population structure, and reproductive biology is not enough. It is very important that ecology and genetics of target species must be fully evaluated if we want their proper and successful conservation (Çınar and Tuğ, 2015; Oztürk et al., 2016).

Most important stage during the life cycle of a plant is its habitat. In view of this most important step in this connection is an evaluation of its habitat features together with the biological features of species. Latter is also critical for the wildlife management. The habitat of a species is informative about bioclimatic, edaphic, topographic, biotic characteristics of a specific area. All these features need a recognition of biotic and abiotic factors of a living being (Thomas, 1979; Eskin et al., 2013). This type of evaluation forms the basis of autecological studies. Many plant autecological studies have been undertaken in Turkiye notable among these are; Vardar and Ahmet (1967), Ahmet (1968, 1969, 1970), Öztürk (1975, 1979, 1982), Öztürk and Görk (1979a,b), Öztürk and Ataç (1982), Alptekin et al. (1990), Özdemir et al. (1991a,b), Uysal and Öztürk (1991, 1993), Uysal et al. (1991, 1992, 1994a,b,c, 1996), Öztürk and Seçmen (1993, 1999), Özdemir and Öztürk (1996), Çelik et al. (2006a,b, 2008), Eskin et al. (2013), Altay et al. (2013, 2016a,b), Eroğlu et al. (2014) and Oztürk et al. (2016). In this study, an attempt has been made to evaluate the edaphic relations of Cirsium cassium.

\section{Materials and Method}

Plant (root, stem and leaf) samples of Cirsium cassium Davis \& Parris (Asteraceae) and soil samples from their growth habitats were collected from three different localities in Hatay (especially from the roads extending between Samandağ and Yayladă Districts). The root, stem, and leaf samples were oven-dried at $80{ }^{\circ} \mathrm{C}$ for 48 hours, milled in micro hammer cutter and passed through $1.5-\mathrm{mm}$ sieve. $0.5 \mathrm{~g}$ of samples was weighed and transferred into Teflon vessel and $8 \mathrm{ml}$ of $65 \% \mathrm{HNO}_{3}$ was added. The samples were mineralized in microwave oven at $145{ }^{\circ} \mathrm{C}$ for $5 \mathrm{~min}$., at $165^{\circ} \mathrm{C}$ for $5 \mathrm{~min}$. and at $175^{\circ} \mathrm{C}$ for $20 \mathrm{~min}$. After cooling, samples were filtered using Whatman filters. The volume was made up to $50 \mathrm{ml}$ with 
ultrapure water. Standard solutions were prepared by using multi element stock solutions-1000 ppm (Merck). The potassium and sodium measurements were conducted by Inductively Coupled Plasma Atomic Emission Spectroscopy (ICP-AES). Nitrogen and phosphorus were determined by the methods outlined in detail in Öztürk et al. (1997).

$500 \mathrm{~g}$ of soil samples were taken from a depth of $30 \mathrm{~cm}$ from all localities. $\mathrm{pH}$ was determined by Hanna $211 \mathrm{pH}$ meter; total soluble salt (TSS) and conductivity values were measured by Hanna E.C. 211 conductivity meter; soil texture was determined with Bouyoucos Hydrometer; $\mathrm{CaCO}_{3}$ was measured by Scheibler calcimeter; modified Kjeldahl method was used for total nitrogen analysis; phosphorus was determined by using Olsen method; all measurements were taken according to the methods outlined in detail in Öztürk et al. (1997), potassium and sodium concentrations were measured by using ICP-AES (Altay et al., 2016a).

\section{Results}

The soil analysis of $C$. cassium reveals that it generally prefers clayey soils with a soil $\mathrm{pH}$ of 7.80-7.92 and EC 242 to $395(\mu \mathrm{S} / \mathrm{cm})$. The values for calcium carbonate lie between 11 to $19(\%)$, nitrogen between 0.010 to 0.282 (\%), phosphorus between 15.950 to $16.925\left(\mathrm{mg} \mathrm{kg}^{-1}\right)$, sodium 34 to $41\left(\mathrm{mg} \mathrm{kg}^{-1}\right)$ and potassium 174.50 to $520.00\left(\mathrm{mg} \mathrm{kg}^{-1}\right)$.

Table 1. Physical and chemical analysis of the soil samples from the study sites

\begin{tabular}{lcc}
\hline & Min.-Max. & Average \\
\hline $\mathrm{pH}$ & $7.80-7.92$ & 7.86 \\
\hline $\mathrm{N}(\%)$ & $0.010-0.282$ & 0.101 \\
\hline $\mathrm{P}(\mathrm{mg} / \mathrm{kg})$ & $15.950-16.925$ & 16.342 \\
\hline $\mathrm{K}(\mathrm{mg} / \mathrm{kg})$ & $174.50-520.00$ & 316.83 \\
\hline $\mathrm{Na}(\mathrm{mg} / \mathrm{kg})$ & $34.00-41.00$ & 37.67 \\
\hline $\mathrm{CaCO}(\%)$ & $11.00-19.00$ & 14.70 \\
\hline $\mathrm{EC}(\mu \mathrm{S} / \mathrm{cm})$ & $242.00-395.00$ & 314.70 \\
\hline $\mathrm{TSS}(\%)$ & $0.125-0.140$ & 0.132 \\
\hline
\end{tabular}

The results of analysis of $C$. cassium of roots, stems and leaves collected during flowering season show that on dry weight basis the nitrogen values range between 0.078 $0.178(\%)$, phosphorus between $0-563\left(\mathrm{mg} \mathrm{kg}^{-1}\right)$, sodium between $250-370\left(\mathrm{mg} \mathrm{kg}^{-1}\right)$ and potassium between 250 $370\left(\mathrm{mg} \mathrm{kg}^{-1}\right)$ in roots. In the stems the nitrogen values range between 0.044-0.060 (\%), phosphorus between 0$100.5\left(\mathrm{mg} \mathrm{kg}^{-1}\right)$, sodium between 390-555 (mg kg$\left.{ }^{-1}\right)$ and potassium between $340-555\left(\mathrm{mg} \mathrm{kg}^{-1}\right)$. In the leaves the nitrogen values range between 0.092-0.153(\%), phosphorus between $0-90\left(\mathrm{mg} \mathrm{kg}^{-1}\right)$, sodium between 105- $615\left(\mathrm{mg} \mathrm{kg}^{-1}\right)$, and potassium betwen 635-10,000 (mg $\mathrm{kg}^{-1}$ ).

Table 2. Chemical analysis of the plant parts (root, stem and leaves) of C. cassium

\begin{tabular}{|c|c|c|c|c|c|c|}
\hline & \multicolumn{2}{|c|}{ Root } & \multicolumn{2}{|c|}{ Stem } & \multicolumn{2}{|c|}{ Leaves } \\
\hline & $\begin{array}{l}\text { Min.- } \\
\text { Max. }\end{array}$ & Average & $\begin{array}{l}\text { Min.- } \\
\text { Max. }\end{array}$ & Average & $\begin{array}{l}\text { Min.- } \\
\text { Max. }\end{array}$ & Average \\
\hline $\mathrm{N}(\%)$ & $\begin{array}{l}0.078- \\
0.178\end{array}$ & 0.116 & $\begin{array}{l}0.044- \\
0.060\end{array}$ & 0.052 & $\begin{array}{l}0.092- \\
0.153\end{array}$ & 0.113 \\
\hline $\begin{array}{l}\mathrm{P} \\
(\mathrm{mg} / \mathrm{kg})\end{array}$ & $0-563$ & 221.33 & $\begin{array}{c}0.00- \\
100.50\end{array}$ & 33.50 & $\begin{array}{r}0.00- \\
90.00\end{array}$ & 58.50 \\
\hline $\begin{array}{l}\mathrm{K} \\
(\mathrm{mg} / \mathrm{kg})\end{array}$ & $\begin{array}{l}250- \\
370 \\
\end{array}$ & 295 & $\begin{array}{l}340- \\
555 \\
\end{array}$ & 456.67 & $\begin{array}{c}635- \\
10,000 \\
\end{array}$ & 4873.33 \\
\hline $\begin{array}{l}\mathrm{Na} \\
(\mathrm{mg} / \mathrm{kg})\end{array}$ & $\begin{array}{l}250- \\
370\end{array}$ & 295 & $\begin{array}{l}390- \\
555\end{array}$ & 473.33 & $\begin{array}{l}105- \\
615\end{array}$ & 291.67 \\
\hline
\end{tabular}

The soil analysis data shows that this endemic taxon prefers clayey-loamy, nonsaline, slightly alkaline soils with high lime content, nitrogen and potassium are at sufficient level, and phosphorus is rich in the soil.

Epstein (1999) has reported that N, P, K and Na values follow as: $1.5 \%, 2,000(\mathrm{mg} / \mathrm{kg}), 10,000(\mathrm{mg} / \mathrm{kg})$ and 10 $(\mathrm{mg} / \mathrm{kg})$ respectively in plants. According to our analysis results of root, stem and leaf parts nitrogen and phosphorus are below normal values in all plant organs; sodium is above the normal value in all plant parts. In addition, potassium values are below normal values in root and stem, but above normal values in leaf.

\section{Discussions}

Endemics and threatened plants are an important part of plant diversity, these are in need of immediate intervention in order to ascertain their long-term survival (Jalli et al., 2015). The strategies for plant conservation include in situ approaches such as, establishing protected areas, national parks, biosphere reserves and gene sanctuaries; whereas ex situ approaches include seed conservation genebanks, field genebanks and in vitro conservation. An application of different conservation approaches will prove helpful in saving plant taxa in danger. It will also widen our knowledge regarding these species. All these will pave way for their sustainable use beneficial for humans (Jalli et al., 2015).

Circium cassium, being a narrow endemic, must be given priority, and monitored carefully in order to preserve the genetic diversity of this species since endemic species are much more vulnerable to extinction at much higher rates than other species. In addition, ecological studies about such endangered endemic taxa should be supported with comprehensive physiological and molecular studies to promote the understanding about the narrow endemics (Altay et al., 2013; 2016a,b; Eroğlu et al., 2014).

\section{Acknowledgments}

This research was supported by Mustafa Kemal University (Project No: 12140).

\section{References}

Altay V, Ozyigit II, Keskin M, Demir G, Yalçın IE (2013). An ecological study of endemic plant Polygonum istanbulicum Keskin and its environs. Pak J Bot 45(S1): 455-459.

Altay V, Karahan F, Oztürk M, Hakeem KR, Ilhan E, Erayman M (2016a) Molecular and ecological investigations on the wild populations of Glycyrrhiza L. taxa distributed in the East Mediterranean Area of Turkey. Journal of Plant Research 129(6): 1021-1032. 
Altay V, Gülyanar Ş, Ozyigit II (2016b). Autecology of Cephalaria taurica Szabó, a narrow endemic from Turkey: Plant-soil interactions. IOSR Journal of Environmental Science, Toxicology and Food Technology 10(9): 90-94.

Ahmet M (1968). Some aspects of the autecology of Ranunculus arvensis. Sci Rep Fac Sci Ege Univ 62: 1-19.

Ahmet M (1969) Some autecological studies of Ranunculus muricatus L. Sci Rep Fac Sci Ege Univ 62: 1-13.

Ahmet M (1970). Ecology of Ranunculus laetus. Phyton 14: 1-8.

Alptekin E, Öztürk M, Zeybek N (1990). Lupinus angustifolius'un Ekolojisi. 10. Ulusal Biyoloji Kongresi, 18-20 Temmuz, Erzurum.

Çelik S, Uysal İ, Menemen Y, Özkan K, Öztürk M (2006a). Ecology and conservation of Centaurea amanicola Hub.-Mor. (Asteraceae) a vulnerable endemic species from Amanous Mountains, Türkiye, ${ }^{\text {st }}$ European Congress of Conservation Biology, Hungary, August.

Çelik S, Özkan K, Gokturk RS, Yücel E, Ozturk M (2006b). Determination of indicator species and comparison of soil characteristics of Centaurea mucronifera DC. and Centaurea pyrrohoblephara Boiss. distributed in Turkey. International Journal of Biology and Tecnology 3(3): 609-617.

Çelik S, Yucel E, Mendes M, Tug GN, Ozturk M (2008). Canonical correlation analysis for studying the relationship between the basic morphological and some soil chemical characteristics of Centaurea mucronifera DC. (Asteraceae). Asian Journal of Chemistry 20(3): 2451-2456.

Çinar IB, Tuğ GN (2015). The Morphology, ecology, and conservation status of the local endemic species Salsola grandis. Ekoloji 24(96).

Eken G, Isfendiyaroğlu S, Yeniyurt C, Erkol IL, Karataş A, Ataol M (2016) Identifying key biodiversity areas in Turkey: a multitaxon approach. International Journal of Biodiversity Science, Ecosystem Services \& Management 12(3): 181-190.

Epstein E (1999). Silicon. Ann Rev Plant Physiol Plant Mol Biol 50: 641-664.

Eroğlu H, Ozyiğit II, Altay V, Yarcı C (2014). Autecological characteristics of Centaurea hermannii F. Herm.: An endemic species from Turkey. Bulgarian Journal of Agricultural Science 20(1): 183-187.

Eskin B, Ozyiğit II, Doğan I, Altay V, Demir G, Serin M (2013). Germination physiology and autecology of Centaurea kilaea Boiss. from Turkey. Sains Malaysiana 42(10): 1473-1482.

Jalli R, Aravind J, Pandey A (2015). Conservation and management of endemic and threatened plant species in India: An overview. In: Bir Bahadur et al. (Eds.), Plant Biology and Biotechnology, Vol.: II Plant Genomics and Biotechnology, pp. 461-486, Springer India.

Oztürk M, Altay V, Aksoy A (2016). Ecology of some endangered endemic plant taxa of Turkiye in relation to climate change. International Scientific Conference within "Day of Kazakhistan", September 3, 2016, EXPO-2016, Antalya-Turkey, pp. $12-15$.

Özdemir F, Pirdal M, Öztürk M (1991a). Marrubium rotundifolium Boiss.'in morfolojisi, anatomisi ve ekolojisi üzerinde araştırmalar. Anadolu Üniversitesi Fen-Ed Fakültesi Dergisi 3/1: 19-26.

Özdemir F, Pirdal M, Öztürk M (1991b). Astragalus tmoleus var. tmoleus Boiss.'in morfolojisi, anatomisi ve ekolojisi üzerinde araştırmalar. Anadolu Üniversitesi Fen-Ed Fakültesi Dergisi 27-35.

Özdemir F, Öztürk M (1996). Batı Anadolu'da yayılış gösteren Capparis L. türlerinin bireysel ekolojisi üzerine bir araştırma. Turkish Journal of Botany 20: 117-125.

Öztürk M (1975). Batı Anadolu'da yayılış gösteren Inula graveolens'in autekolojisi hakkında araştırma. Doçentlik Tezi, Ege Üniv Fen Fak Sistematik Botanik Kürsüsü İzmir.

Öztürk MA (1979). Preliminary observation on the edaphic and biotic relations of Myrtus communis L. Ege Univ Fen Fak Dergisi Seri B III 1-2-3-4: 137-142.

Öztürk M (1982). Inula graveolens (L.) Desf.'in ekofizyolojisi, II edafik ilişkileri. Ata Univ Fen Fak Der 2(Özel Say1 1): $480-492$.

Öztürk M, Görk G (1979a). Ecology of Mentha pulegium. Ege University Science Faculty Journal III: 57-72.

Öztürk M, Görk G (1979b). Edaphic relations of Mentha species in West Anatolia. Ege University Science Faculty Journal III: 95-110.

Öztürk MA, Ataç E (1982). Bazı Pistacia türlerinin anatomisi ve ekolojisi üzerinde bir çalışma. Atatürk Üniversitesi Fen Fakültesi Dergisi 2(Özel sayı): 493-508.

Öztürk M, Seçmen O (1993). Autecological studies in Turkey. V. OPTIMA Collogium, Istanbul.

Öztürk M, Seçmen Ö (1999). Plant Ecology. 5th ed., Ege Univ. Press, Izmir.

Öztürk M, Pirdal M, Özdemir F (1997). Bitki Ekolojisi Uygulamalari. Ege Universitesi Basimevi Bornova-Izmir.

Thomas JW (1979). Wildlife habitats in managed forests: The Blue Mountains of Oregon a Washington. U.S.D.A. Forest Service. Handbook 553, Washington, D.C.

Uysal İ, Öztürk M (1991). Digitalis trojana Ivan. endemik türünün morfolojisi, anatomisi ve ekolojisi. Anadolu Üniversitesi FenEdebiyat Fakültesi Dergisi 3(1): 53-61.

Uysal İ, Öztürk M (1993). Morphology, anatomy and ecology of endemic species Papaver virchowii Aschers and Sint. S U Fen Edebiyat Fakultesi Fen Dergisi 11: 105-115. 
Uysal İ, Ozturk M, Pirdal M (1991). Sideritis trojana Bornm, endemik türünün morfolojisi, anatomisi ve ekolojisi. Doğa-Tr J of Botany 15: 371-379.

Uysal İ, Öztürk M, Pirdal M (1992). Morphology, anatomy and ecology of endemic species Dianthus ingoldbyi Turril. Ege Univ Science Faculty Journal 14: 30-38.

Uysal İ, Öztürk M, Pirdal M (1994a). Morphology, anatomy and ecology of Colchicum burttii Meikle. XII National Biol Congress, 6-8 July, Edirne.

Uysal İ, Öztürk M, Pirdal M (1994b). Morphology, anatomy and ecology of Campanula lyrata Lam. subsp. lyrata. XII. National Biol. Congress, 6-8 July, Edirne, pp. 247-251.

Uysal İ, Öztürk M, Pirdal M (1994c). Morphology, anatomy and ecology of Aristolochia hirta L. XII. National Biol. Congress, 68 July, Edirne, pp. 252-256.

Uysal İ, Pirdal M, Öztürk M (1996). Alyssum pinifolium (Nyar) Dudley'in morfolojisi, anatomisi ve ekolojisi. Hacettepe Fen ve Mühendislik Bilimleri Dergisi 17: 105-120.

Vardar Y, Ahmet M (1967). Some ecological aspect of Myrtus communis L. Bot J Hrb Syst 93: 652-667.

Cite this article: Altay V, Daloğlu MY, Öztürk M (2017). Edaphic relations of Cirsium cassium Davis \& Parris (Asteraceae), a local endemic from Hatay (Turkey). Anatolian Journal of Botany 1(2): 41-44. 